\title{
Factors Affecting Palm Farmers' Decisions to Dispense Plantage-Product Zakat in Labuhanbatu Selatan Regency
}

\author{
Amalia Agustin Syn, Khalifah Muhammad Ali, and Didin Hafidhuddin \\ Bogor Agricultural University
}

\begin{abstract}
Zakat is one of the five points in rukun Islam and consists of two types: zakat nafs (soul) and zakat maal (wealth). One of the many kinds of zakat maal is plantage-product zakat. Labuhanbatu Selatan Regency is an area that contains 160,785.04 hectares of palm plantation land as recorded in 2016. The area also produced 7,493,696.18 tons of Fresh Fruit Bunches (FFB) in the same year. The objective of this study is to identify the potential of plantage-product zakat (specifically palm plantage) and analyze the factors that affect farmers' decision to dispense plantage-product zakat in Labuhanbatu Selatan Regency. Logistic regression analysis was the method of analysis used in this study. Based on data obtained from Dinas Perkebunan Provinsi Sumatera Utara 2016, the potential of plantageproduct zakat in Labuhanbatu Selatan Regency reached 25.6 billion rupiahs in 2014; 21.6 billion rupiahs in 2015, and 370.4 billion rupiahs in 2016. The variables that significantly affected farmers' decisions to dispense plantage-product zakat were comprehension of zakat, faith, rewards, Islamic study, and frequency of worship.
\end{abstract}

Keyword: Logistic Regression Analysis, Labuhanbatu Selatan Regency, Plantage-Product Zakat Potential.

\section{INTRODUCTION}

Zakat (alms) is the third point in rukun Islam - Islamic acts - and is considered to be a major pillar of Islam. The divine command regarding zakat is clearly stated in Qur'an Surah At-Taubah, verse 103: "Of their goods, take alms, that so thou mightest purify and sanctify them; and pray on their behalf. Verily the ibadahs are a source of security for them: And Allah is One Who heareth and knoweth." Zakat is deemed to be capable of enhancing equality in the economic sector by improving the living standards of mustahiks. Therefore, in various different countries, zakat serves as an alternative tool for overcoming economic inequality. Zakat as a form of wealth is given out by a muzaki - a Muslim that gives zakat - to mustahik - people who are eligible to receive zakat - when the wealth meets various conditions according to Islamic law. This is in line with the divine command in Qur'an Surah At-Taubah, verse 60, which explains the following eight asnaf of mustahik: fakir, miskin, amil, mualaf, riqab, gharim, sabilillah, and ibnu sabil. These translate as poor people with a job, poor people without a job, people who have converted to Islam, slaves, people who collect the zakat, people in debt arising from daily basic needs, people who are striving for Islam, and people who are on a journey, provided there is no contravention of any Islamic principle. 
Table 1. National Zakat Potential

\begin{tabular}{lc}
\hline Sector & Zakat Potential (trillion rupiahs) \\
\hline Household zakat potential & 82.7 \\
BUMN zakat potential & 2.4 \\
Private industry zakat potential & 114.9 \\
Savings zakat potential & 17.0 \\
Total national zakat potential & 217.0 \\
\hline
\end{tabular}

Source: BAZNAS and FEM IPB (2011)

From Table 1 we can observe the national zakat potential in Indonesia across a number of sectors, as follows: household zakat potential, BUMN zakat potential, private industry zakat potential, and savings zakat potential, with a total national zakat potential reaching 217 trillion rupiahs (BAZNAS and FEM IPB, 2011). This huge potential of zakat has been noticed by the government, specifically the Ministry of BAPPENAS. Subsequently, BAPPENAS coordinated with OPZ - a zakat organization - to integrate the zakat program into a national program as part of the drive for the attainment of the Sustainable Development Goals (SDGs). Besides that, BAPPENAS also included zakat in the Masterplan Arsitektur Keuangan Syariah Indonesia (MAKSI) - Indonesia's Islamic Finance Architecture Masterplan - that was published in 2015. Based on MAKSI, BAZNAS has the role of coordinator for the arrangement, collection, and distribution of zakat at the national level, with the Ministry of Religion as the regulator and superintendent for BAZNAS performance (BAZNAS 2016).

There are two types of zakat, namely zakat nafs (fitrah/soul) that is mandatory to be given out at the end of Ramadhan, and zakat maal (wealth), which includes business revenue, wages/salaries, mining, agriculture, marine products, farming, plantage products, treasure, gold, and silver. Each type of zakat has its own nishab, which is the minimum amount of wealth to be distributed as zakat. Nowadays, the definition of zakat maal is not restricted only to wealth that can be used generally, but also includes amendable wealth, such as plantage-product. Every plantation that has economic value, except for those that are haram, or prohibited, is obliged to distribute this wealth as zakat once it reaches the nishab. This is in line with the divine command stated in Qur'an Surah Al-An'am, verse 141: "It is He who produceth gardens, with trellises and without, and dates, and tilth with produce of all kinds, and olives and pomegranates, similar (in kind) and different (in variety): eat of their fruit in their season, but render the dues that are proper on the day that the harvest is gathered." Whatever plantation that is not a staple food is not obliged to be given out as zakat, except for those that are put up for sale and from which an income of more than 200 dirhams would need to be given out zakat equal to five dirhams. Based on this notion, annual plantage-product, including palm, is analogized as business zakat. With such an analogy, the nishab of plantageproduct is also equal to that of business zakat, namely 85 grams of gold, and this amount needs to be held for at least one year. If these conditions are met, then it is obligatory to dispense the wealth as zakat equal to 2.5 percent of the total wealth (Zuhri, in Qardhawi, 2011)

Indonesia is a predominantly agrarian economy, with palm as one of its principal commodities. Palm production in Indonesia reached $31,070,015$ tons in 2015. North Sumatra Province is one of the regions in Indonesia that produces a high quantity of palm, accounting for the second-highest production in Indonesia, behind Riau Province in first place. In 2015, its palm production reached 
$5,193,135$ tons. These data demonstrate the huge potential of palm and the demand that exists in both local and international markets. Palm is one of Indonesia's principal plantage products and a major source of income for the country (Ministry of Agriculture, 2015).

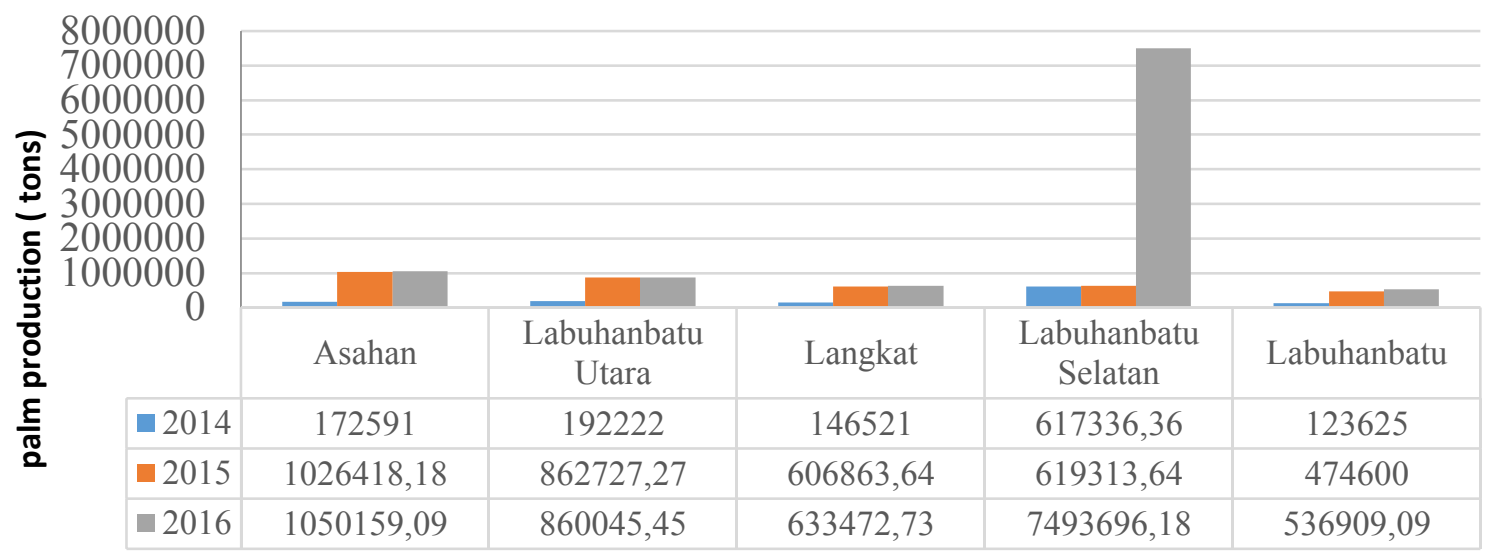

Figure 1. The five regencies with the highest Fresh Fruit Bunches (FFB) production in North Sumatra Province, 2016

The total plantage area in Labuhanbatu Selatan is no greater than that found in the other regencies of North Sumatra Province; however, it achieves a considerably greater volume of palm production. Figure 1 shows the five regencies with the highest FFB production in North Sumatra Province. Labuhanbatu Selatan has not always occupied first place in terms of the highest FFB production; however, its land is considerably more productive than that in the other four regencies. One hectare of palm land in Labuhanbatu Selatan can produce 500 to 600 kilograms of FFB in one harvest period, with the province capable of producing up to three harvests per month. Meanwhile, the other three regencies with production above that of Labuhanbatu Selatan were only able to produce a maximum of 400 kilograms in one harvest, with a maximum of one to two palm harvests per month. Labuhanbatu Selatan produced $617,336.36$ tons of FFB in $2014 ; 619,313.64$ tons in 2015, and $7,493,696.18$ tons in 2016 (BPS Sumut, 2016).

If the average selling price of palm during the period 2014-2016 ranged from Rp 1,400 to $\mathrm{Rp} 1,900$ per kilogram, then one hectare of palm land was capable of generating Rp 1,400,000 to Rp 3,420,000 per month. Based on this, with a minimum 3.5hectare area of productive palm land, palm production is capable of generating an

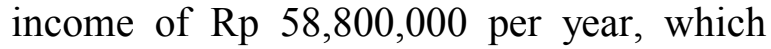
meets the nishab of plantage-product zakat following conversion to the average price of gold for the corresponding year. Based on this condition, a palm farmer is obliged to distribute plantage-product zakat. However, many farmers lack comprehension of plantage-product zakat, meaning that, in practice, they do not distribute it. Based on these notions, the major problems to be addressed by this study are as follows:

(1) What is the plantage-product (palm) zakat potential in Labuhanbatu Selatan?

(2) What factors affect farmers' decisions to give out plantage-product zakat in Labuhanbatu Selatan Regency?

The objective of this study is to describe the palm zakat potential in Labuhanbatu Selatan and to analyze the factors affecting a farmer's decision to give out palm zakat in Labuhanbatu Selatan. 


\section{LITERATURE REVIEW}

Pertiwi (2017) with respect to the factors that affect the decision by rice farmers to dispense agricultural zakat in Kebumen Regency, the amount of agricultural zakat given out by the farmers was $\mathrm{Rp}$ $191,051,720,000$ for ten percent zakat, and $\mathrm{Rp} 95,525,851,000$ for five percent zakat. The variables that significantly affected agricultural zakat were faith, altruism, education level, and a dummy of Islamic study .

Prastyawan (2016) seeking to identify the factors affecting a farmer's willingness to pay (WTP) plantage-product zakat in Lampung Timur, showed these to be education level, faith level, altruism, and a dummy of Islamic study. In that study, only 70.6 percent of the farmer respondents were obliged to give zakat. This was demonstrated by the measurement result and the WTP estimation on the payment of agricultural zakat for each $\mathrm{Rp} 1,000,14000$ of $\mathrm{Rp} 17,647$ per month. This result indicated the considerably high level of farmers' WTP regarding zakat. A total of six variables were measured in the study. Two were found to have no significant effect on the model, while the other four were found to have a significant effect .

Hanapi (2014) found fuqaha (an expert in Islamic law), the base of accountancy for agricultural zakat stipulates the types of plantation that are obliged to distribute zakat and also the type of zakat that is applied to non-staple plantations in Malaysia, in addition to determining the method to be used. The study in question was a literary study. The results indicated that non-staple plantations need to give out zakat, which is a conclusion based on the concept of wealth. Nowadays, most nonstaple foods are in the form of commercial goods that yield a profitable result. Meanwhile, the type of zakat that is applied to a plantation depends on its reason.

Mukhlis (2013) found the case study from Bogor Regency to see the factors that affect people's obedience in giving out zakat. The study used factor analysis, with the results indicating the presence of several factors affecting people's obedience in giving out zakat, as follows: religious reasons such as faith, religious comprehension, and religious rewards. There were also other factors such as social care, self-satisfaction, and organization. These results serve to emphasize that in order to increase the amount of zakat collection, the focus of socialization should not be restricted only to religious reasons but should also include a social aspect, selfsatisfaction, and organization .

Muda (2006) conducted an exploratory investigation into the factors influencing individual participation in zakat contribution, this was an exploratory investigation. The study employed factor analysis as its method, with the results indicating that the following factors motivated muzaki in their zakat contribution: altruism, religion, self-satisfaction, and organization. Based on the result of the study, organization exerted an important influence on the muzaki's motivation in giving out zakat since most of the respondents mentioned that they gave out zakat because of their satisfaction with the service provided by the zakat institution/organization, which was deemed to be responsible in its management of zakat.

\section{RESEARCH METHODOLOGY}

Two types of data were used in this study: primary data and secondary data. The primary data were obtained from interviews conducted directly with the farmer respondents, accompanied by a questionnaire. Meanwhile, the secondary data were obtained from agriculture commodity reports published by Dinas Perkebunan Sumatera Utara, Badan Pusat Statistik Sumatera Utara, BAZNAS, books, and other institutions involved in this area. Descriptive analysis was the method used to estimate plantage-product zakat potential. Meanwhile, logistic regression analysis was 
used to analyze the factors that affect a farmer's decision to give out zakat. The analysis tools used were the software Statistical Product and Service Solution (SPSS) 24 and Microsoft Excel 2016. The descriptive analysis was conducted using the following two approaches: (1) a quantitative approach with the data displayed in the form of graphs/tables, and (2) a qualitative approach comprising respondent interviews. Palm zakat potential was analyzed by estimating the total palm production. Plantage-product zakat was measured using the concepts from the zakat profession. Palm farmers derive their income from palm plantage; therefore, zakat potential was measured based on the plantage-product zakat. The nishab is 85 grams of gold, with as much as 2.5 percent of the total income needing to be given out.

\section{Plantage-Product Zakat $=$ Total palm production $x$ palm price $x 2.5$ percent}

Logistic regression analysis describes the correlation between independent variables $(\mathrm{X})$ and a dependent variable $(\mathrm{Y})$ using a certain mathematic model. The dependent variable (Y) was not inserted directly into the logistic regression model to be estimated along with the independent variables; instead, it was transformed into a logit variable as a natural logarithm ( 0 and 1). 0 Always for the "no" or "not" category. While the number 1 is now used to describe the respondent who corresponds to the purpose of the study. The dependent variable is a categorical type of data or, more specifically, a dichotomous type of data.
Logistic regression was used to analyze the likelihood of farmers dispensing plantageproduct zakat using the model set out as follows:

$$
\begin{aligned}
& \mathrm{Z}_{\mathrm{i}}=\mathrm{Z}_{\mathrm{n}}\left(\frac{\mathrm{Pi}}{1-\mathrm{Pi}}\right)=\beta_{0}+\beta_{1} \mathrm{PHZ}_{\mathrm{i}}+\beta_{2} \mathrm{KMN}_{\mathrm{i}}+ \\
& \beta_{3} \mathrm{PHR}_{\mathrm{i}}+\beta_{4} \mathrm{KPD}_{\mathrm{i}}+\beta_{5} \mathrm{ALT}_{\mathrm{i}}+\beta_{6} \mathrm{PGJ}_{\mathrm{i}}+ \\
& \beta_{7} \mathrm{FSI}_{\mathrm{i}}+\varepsilon_{\mathrm{i}}
\end{aligned}
$$

where:

$Z_{i} \quad=$ the chance of a farmer giving out plantage-product zakat (1 for "gives out zakat" and 0 for "does not give out zakat")

$\beta_{0} \quad=$ Constant

$\beta_{1} \beta_{7}=$ Regression coefficient

$P H Z_{i}=$ Comprehension of zakat

$K M N_{i}=$ Faith

$P H R_{i}=$ Rewards

$K P D_{\mathrm{i}}=$ Self-satisfaction

$A L T_{i}=$ Altruism

$P G J_{i}=$ Islamic study

$F S I_{i}=$ Ibadah frequency

$\varepsilon_{i} \quad=$ Error

$i \quad=$ Respondent-i $(\mathrm{i}=1,2,3, \ldots, \mathrm{n})$

\section{RESULTS AND DISCUSSION}

A significantly large plantation with high productivity is expected to have a huge plantage-product zakat potential. Details of the plantage-product zakat potential for the last three years can be seen in Table 2 . Plantage-product zakat is measured by multiplying the total production by the commodity price in the corresponding year, then summing them up.

Table 2. Plantage-product zakat potential in Labuhanbatu Selatan

\begin{tabular}{rrrrc}
\hline Year & Land Area (Ha) & Total production (Tons) & Price $(\mathrm{Rp} / \mathrm{Kg})$ & $\begin{array}{c}2.5 \text { percent zakat } \\
\text { potential (million) } \\
\text { rupiahs) }\end{array}$ \\
\hline 2014 & $42,544.00$ & $617,336.36$ & 1,659 & 25.6 \\
\hline 2015 & $42,567.00$ & $619,313.64$ & 1,400 & 21.6 \\
\hline 2016 & $160,785.04$ & $7,493,696.18$ & 1,977 & 370.4 \\
\hline
\end{tabular}

Source: Dinas Perkebunan Sumatera Utara (processed) 
Based on Table 2, there is a huge amount of palm land in Labuhanbatu Selatan, with a corresponding very sizable total amount of palm production. The land area given in the table is the total sum of Productive Plant (PP), Pre-Productive Plant (PPP), and Unproductive Plant (UP). The year 2016 saw a significant increase in total production in line with an increase in the amount of land area.

Knowledge of zakat eventually leads farmers to give out zakat, including zakat nafs and zakat maal. Each respondent had their own perspective on the benefits of zakat. A total of 24 respondents stated that zakat is an obligatory act for Muslims, while 5 respondents stated that zakat is a manifestation of faith. A total of 66 respondents stated that zakat is a tool by which to cleanse wealth, with 5 respondents stating that zakat is an example of an act of humanity by helping others in need.

\section{Factors Affecting Farmers' Decisions to Give Out Plantage-Product Zakat}

A number of independent variables were identified in this study as the factors deemed to affect farmers' decisions to give out plantage-product zakat. They were zakat comprehension, faith, rewards, selfsatisfaction, Islamic study, and ibadah frequency. The dependent variable in this study comprised two probabilities: (1) the respondent gives out plantage-product zakat $(\mathrm{Y}=1)$, and (2) the respondent does not give out plantage-product zakat $(\mathrm{Y}=0)$.

Table 3. Logit estimation result

\begin{tabular}{|c|c|c|c|c|}
\hline \multirow[b]{3}{*}{ Observed } & & \multicolumn{3}{|l|}{ Predicted } \\
\hline & & \multicolumn{2}{|l|}{ Zakat } & \multirow[t]{2}{*}{ Percentage Correct } \\
\hline & & $\begin{array}{l}\text { Does not give } \\
\text { out zakat }\end{array}$ & $\begin{array}{l}\text { Gives out } \\
\text { zakat }\end{array}$ & \\
\hline \multirow[t]{2}{*}{ ZAKAT } & $\begin{array}{l}\text { Did not give } \\
\text { out zakat }\end{array}$ & 33 & 4 & 89.2 \\
\hline & $\begin{array}{l}\text { Gave out } \\
\text { zakat }\end{array}$ & 5 & 58 & 92.1 \\
\hline Overall $P$ & & \multicolumn{3}{|c|}{91.0} \\
\hline
\end{tabular}

Source : Primary data 2018 (processed)

The results in Table 3 show that the percentage correct of 91.0 percent represented the overall classification result. The regression model is therefore considered to be fit. According to the result above, the percentage correct for the estimated classification of respondents that did not give out zakat was 89.2 percent. This means, out of the 37 respondents who stated that they did not give out zakat, in practice 33 did not give out zakat, while the other 4 respondents did actually give out plantage-product zakat. Meanwhile, the percentage correct for the estimated classification of respondents that gave out zakat was 92.1 percent. This means that, out of the 63 respondents who stated that they gave out zakat, 5 respondents actually did not give zakat, while the other 58 respondents did give out zakat. 
Table 4. Logistic Regression Output of Classification Table, Omnibus Test of Model Coefficients, Model Summary, and the Hosmer-Lemeshow test

\begin{tabular}{|c|c|c|}
\hline \multicolumn{3}{|c|}{ Classification Table } \\
\hline Overall Percentage & & 91.0 \\
\hline \multicolumn{3}{|c|}{ Omnibus Test of Model Coefficients } \\
\hline Chi-square & $D f$ & Sig. \\
\hline 89.472 & 7 & 0.000 \\
\hline \multicolumn{3}{|c|}{ Model Summary } \\
\hline $\begin{array}{c}-2 \text { Log Likelihood } \\
25.140\end{array}$ & $\begin{array}{c}\text { Cox \& Snell R-squared } \\
0.591\end{array}$ & $\begin{array}{c}\text { Nagelkerke R-squared } \\
0.867\end{array}$ \\
\hline \multicolumn{3}{|c|}{ Hosmer-Lemeshow test } \\
\hline $\begin{array}{l}\text { Chi-square } \\
0.083\end{array}$ & $\begin{array}{c}D f \\
8\end{array}$ & $\begin{array}{l}\text { Sig. } \\
1.000\end{array}$ \\
\hline
\end{tabular}

The Model Summary indicates a Nagelkerke R-squared value of 0.867 , while the Cox \& Snell R-squared value was 0.591. This shows that the independent variables could explain 86.7 percent of the model, with other variables outside of the model explaining the remaining 13.3 percent. The HosmerLemeshow Test, which describes the goodness of the model, showed the chisquare value to be 0.083 , which was significant at the 0.05 significance level. Therefore, it can be stated that the value of the regression analysis is reliable (Sarwono, 2009).

Table 5 shows that the variables of zakat comprehension, faith, rewards, and ibadah frequency significantly affected the dependent variable. The logistic regression model demonstrated that the independent variables significantly affected the dependent variable at the 95 and 90 percent significance levels. The variables of faith, Islamic study, and ibadah frequency significantly affected the dependent variable at $\alpha<0.05$. Specifically, $0.034<0.05$ for the variable of faith, $0.034<0.05$ for Islamic study, and $0.021<0.05$ for ibadah frequency. The variables that affected the dependent variable at the $90 \quad(\alpha<0.1)$ percent significance level were comprehension of zakat and rewards. Specifically, $0.073<0.1$ for the variable of zakat comprehension, and $0.055<0.01$ for rewards. Meanwhile, the variables of self-satisfaction and altruism had no significant effect on the dependent variable. Each independent variable had a different value for the odds ratio. This was because of the different chances of the variables in affecting a farmer's decision to give out plantageproduct zakat.

Table 5. Results of the logistic regression analysis on the "variable in the equation"

\begin{tabular}{llll}
\hline Variable & $\mathrm{B}$ & Sig. & $\operatorname{Exp}(\mathrm{B})$ \\
\hline Comprehension of Zakat & 4.732 & $0.073^{* *}$ & 79.198 \\
Faith & 0.892 & $0.034^{*}$ & 2.439 \\
Rewards & 2.751 & $0.055^{* *}$ & 15.656 \\
Ibadah Frequency & 1.062 & 0.291 & 2.893 \\
Islamic Study & 1.648 & 0.182 & 4.340 \\
Self-Satisfaction & -2.811 & $0.034^{*}$ & 0.060 \\
Altruism & 0.680 & $0.021^{*}$ & 1.975 \\
Constant & -85.050 & 0.041 & 0.000 \\
\hline
\end{tabular}

*Significant at 5\%

** Significant at $10 \%$ 
Variable of Comprehension of Zakat

The variable of zakat comprehension was deemed to represent the respondents' comprehension of zakat, including zakat nafs and zakat maal. Based on the logistic regression analysis, this variable had an odds ratio of 79.198, which was shown by the value of its $\operatorname{Exp}(B)$. This indicated that the farmers who has considerably deep comprehension towards zakat, had the 79.198 times higher chance to give out zakat than the farmer who has considerably shallow comprehension towards zakat, ceteris paribus. One of the respondent who is a religion teacher stated that he already understand the concept of zakat maal since a long time ago. He added that zakat maal which was given out by him was purely from palm-plantage and did not mixed up with his other income sources. He also added that many farmers which voluntarily set aside some amount of their farming profit to be given out, did not understand the objective of the act. As for them who understand the concept of zakat but do not understand. He measurement, tend to mix his plantage income with the other income. These facts indicated that muzaki's comprehension towards zakat is an important aspect in the attainment of boosting zakat collection which eventually contributes to the decrease of economic inequality for both short and long term economyThis finding is in line with the divine command found in Qur'an Surah Al-Mujaadilah, verse 11: "Allah will rise up, to (suitable) rank and (degrees), those of you who believe and who have been granted knowledge."

\section{Variable of Faith}

The variable of faith describes the relationship between a human being and God that is represented by his behavior, which is in line with the divine command. The odds ratio for the variable of faith was 2.439. This indicates that farmers with a high level of faith had a 2.439 times greater chance of giving out zakat than those farmers with a lower level of faith, ceteris paribus. One of the respondents stated that the act of zakat is proof that he is grateful for his God's mercy. This corresponds to the divine revelation that states: "Those who believe, and do deeds of righteousness, and establish regular ibadahs and regular charity, will have their reward with their Lord: on them shall be no fear, nor shall they grieve" (Q.S. AlBaqarah: 277).

\section{Variable of Rewards}

The variable of rewards represents the respondents' expectation of God's and society's rewards for giving out zakat, such as blessing and prosperity from God, and also praise or respect from other people. The odds ratio for the variable of rewards was 15.656, indicating that the farmers who felt highly appreciated and rewarded had a 15.656 times greater chance of giving out zakat than those who did not feel appreciated and rewarded, ceteris paribus. Several of the respondents stated that their income and prosperity increased if they set aside some amount of their profit to be given out to the orphans and widows in their neighborhood, and they also felt satisfaction and happiness when they were praised for their good deeds. These statements indicate that rewards motivate farmers to routinely dispense plantage-product zakat.

\section{Variable of Ibadah Frequency}

The variable of ibadah frequency describes how often the farmers undertake their daily ibadah, in terms of both wajib (obligatory) and sunnah (voluntary). The representative ibadahs in this study were shalat, sunnah fasting, infak (charity), and several other ibadahs. The odds ratio for the variable of ibadah frequency was 1.975, thus indicating that those farmers who had a considerably higher ibadah frequency had a 1.975 times greater chance of giving out 
zakat than those farmers with a considerably lower ibadah frequency, ceteris paribus. One of the respondents, who is a religious figure in Kotapinang District, stated that ibadah is not restricted to shalat or zakat. Numerous small good deeds would also be counted as ibadah; moreover, zakat is already predetermined and even stated as a pillar of Islam. These facts show how the farmers' religious obedience affected their behavior and their decisions to give out plantage-product zakat. Basically, zakat is an ibadah that is commanded for Muslims, as stated in the divine revelation, "Worship none but Allah, treat with kindness your parents and kindred, and orphans and those in need; speak fair to the people; be steadfast in prayer; and practise regular charity" (QS Al-Baqarah verse 83).

\section{Variable of Islamic Study}

The variable of Islamic study describes the period devoted by people to Islamic study and knowledge that was obtained from the study. The odds ratio for the variable of Islamic study was 0.060 . This indicated that those farmers with a considerably higher level of Islamic study had a 0.060 times greater chance of giving out zakat than those farmers with a considerably lower level of Islamic study, ceteris paribus. The variable of Islamic study had a negative effect on the farmers' decision to give out zakat. This occurred since most of the Islamic study forums that the farmers attend tended to involve a discussion of Muslims' attitudes toward other Muslims, while knowledge of zakat was only discussed during Ramadhan, in addition to being restricted only to zakat fitrah. Knowledge regarding zakat maal was very limited and hard to obtain in the Islamic study forums; indeed, if it was present at all, then it tended to cover only a very basic or brief concept, without any detail. One of the respondents who attended an Islamic study forum stated that he had attended the forum three times a week and had never heard any discussion regarding zakat maal.

\section{Variable of Self-Satisfaction}

The variable of Self-Satisfaction in this study describes the respondents' satisfaction after helping others through zakat. The significance value of the variable of self-satisfaction exceeded 0.100 , which means this variable did not significantly affect the farmers' decision to give out zakat. The odds ratio for this variable was 2.893, thus showing that those farmers with considerably higher self-satisfaction had a 2.893 times greater chance of giving out zakat than those farmers with a considerably lower selfsatisfaction, ceteris paribus. One of the respondents stated that zakat was one of the things that made him happy. He added that when he witnessed someone else thanking him or smiling at him, he felt as though he always wanted to help others in need.

\section{Variable of Altruism}

The variable of altruism in this study describes the farmers' level of social care that drives them to give out plantageproduct zakat. Social care is represented by the farmers' attitude of wishing to give out some amount of their wealth to people in need, especially mustahik. The significance value of the variable of altruism exceeded 0.100 , indicating that this variable did not significantly affect the farmers' decision to give out zakat. The odds ratio for the variable of altruism was 4.340, which shows that those farmers who had considerably higher altruism also had a 4.340 times greater chance of giving out zakat than farmers with a considerably lower level of altruism, ceteris paribus. One of the respondents stated that giving out zakat reminded him of his past, whereby he had attended school with the help of zakat funds. His recent economic status as a muzaki made him understand 
the hustle of life. This respondent added that giving out zakat meant helping others in need. This is in line with the divine revelation in the Qur'an: "Seest thou one who denies the judgment (to come)? Then such is the (man) who repulses the orphan (with harshness), and encourages not the feeding of indigent" (Qs. Alma'un verse 1$3)$.

\section{CONCLUSION}

Based on the results of this study, there are several conclusions that can be drawn. First, zakat potential reached 25.6 billion rupiahs in $2014 ; 21.6$ billion rupiahs in 2015, and 370.4 billion rupiahs in 2016. These figures were obtained using a calculation that multiplied the commodity price, total commodity production, and 2.5 percent (zakat amount). This huge potential is expected to offer an alternative solution to the problem of inequality by increasing the living standards of mustahik. The variables that significantly affected farmers' decisions to give out zakat at the 95 percent significance level $(\alpha<0.05)$ were faith, Islamic study, and ibadah frequency. The variables that significantly affected the farmers' decision to give out zakat at the 90 percent significance level $(\alpha<0.01)$ were comprehension of zakat, and rewards. Meanwhile, the variables of selfsatisfaction and altruism were shown to have no significant effect on the model.

\section{REFERENCES}

[ANTAM] Aneka Tambang. 2017. Harga Emas Hari Ini. Retrieved from http://www.antamgold.com/hargaemas-hariini.

[BAZNAS] Badan Amil Zakat Nasional. 2018. Zakat Perniagaan. Retrieved from http://pusat.baznas.go.id/zakatperni agaan/.
[BAZNAS] Badan Amil Zakat Nasional. 2016. Potensi Zakat Nasional:

Peluang dan Tantangan Pengelolaan. Retrieved from https://puskasbaznas.com/images/p pt/Panel-1_Yusuf-WIbisono.pdf.

[BPS Sumut] Badan Pusat Statistika Sumatera Utara. 2016. Data Statistik Berdasarkan Komoditas. Retrieved from https://sumut.bps.go.id/.

[BPS] Badan Pusat Statistik. 2011. Populasi Muslim dalam Angka Tahun 2010. Retrieved from https://www.bps.go.id/.

Brotheridge, C. M., \& Lee, R. T. (2010). Hands to work, heart to God. Religiosity and organizational behavior. Journal of Management, Spirituality \& Religion, 4(3), 287309.

[Disbun Sumut] Dinas Perkebunan

Sumatera Utara. 2016. Harga Komoditi. Retrieved from http://disbun.sumutprov.go.id/harga -komoditi/.

[Disbun Sumut] Dinas Perkebunan Sumatera Utara 2016. Statistik

Perkebunan. Retrieved from http://disbun.sumutprov.go.id/statis tik 2017/.

[Disbunper Labuhanbatu Selatan] Dinas Perkebunan dan Peternakan Kabupaten Labuhanbatu Selatan. 2016. Data Tahunan Perkebunan Kabupaten Labuhanbatu Selatan. Labuhanbatu Selatan. Disbunper

Fauzi, A. (2014). Ekonomi sumber daya alam dan lingkungan teori dan aplikasi. Jakarta (ID). Gramedia Pustaka Utama.

Firdaus, M., Wiramanggala, J., \& Sasongko, H. (2013). Aplikasi metode kuantitatif untuk manajemen dan bisnis. Bogor (ID). IPB Press.

Firdaus, M., \& Irfan, S. B. (2011). Potensi zakat rumah tangga nasional. Iqtishodia Jurnal Ekonomi Islam Republika. 
Hafidhuddin, D., \& Rahmat, P. (2008). Kaya Karena Berzakat. Jakarta (ID). Raih Asa Sukses.

Hafidhuddin, D. (2007). Agar Harta Berkah dan Bertambah. Jakarta (ID). Gema Insani.

Hafidhuddin, D. (2002). Zakat dalam Perekonomian Modern. Jakarta (ID). Gema Insani.

Hanapi, M. S. (2014). Agricultural zakat accounting in Malaysia. International Journal of Business and Social Science, 5(5)(1)).

Huda, N., Rini, N., Mardoni, Y., \& Putra, P. (2012). The analysis of attitudes, subjective norms, and behavioral control on muzaki's intention to pay zakah. International Journal of Business and Social Science, 3(22), 271-279.

Ibrahim, P. (2008). Pembangunan ekonomi melalui agihan zakat: Tinjauan empirikal. Jurnal Syariah, 16, 223244.

[Kementan] Kementerian Pertanian. 2016. Basis Data Statistika Pertanian: Berdasarkan Komoditi. Retrieved from

http://aplikasi.pertanian.go.id/bdsp/ hasil kom.asp.

[Kementan] Kementerian Pertanian. 2016. Basis Data Statistika Pertanian: Berdasarkan Lokasi. Retrieved from

http://aplikasi.pertanian.go.id/bdsp/ hasil kom.asp.

[Kementan] Kementerian Pertanian. 2016. Basis Data Statistika Pertanian: Berdasarkan Indikator. Retrieved from

http://aplikasi.pertanian.go.id/bdsp/ hasil kom.asp.

Muda, M., Marzuki A., \& Shaharuddin A. (2006). Factors Influencing Individual Participation In Zakat Contribution. Exploratory Investigation. Islamic University College of Malaysia (KUIM).
Mufraini, A. M. (2006). Akuntansi dan manajemen zakat. Mengomunikasikan kesadaran dan membangun jaringan. Jakarta (ID). Kencana Prenada Media Grup.

Murtala, M., Mohamad, M. H. S., \& Adnan, M.A. (2011). Antecedents of zakat payers' trust: The case of Nigeria. International Journal of Economics, Management \& Accounting.

Nazir, M. (2005). Metode penelitian. Jakarta (ID). Ghalia Indonesia.

Pertiwi, A. (2017). Analisis Faktor yang Memengaruhi Petani dalam Membayar Zakat Pertanian di Kabupaten Kebumen. [skripsi]. Bogor (ID). Institut Pertanian Bogor.

Prastyawan, W. (2016). Analisis Kesediaan Membayar (WTP) dan Faktor yang Memengaruhi Petani Kakao dalam Membayar Zakat Perkebunan (Kasus Desa Bandar Agung Kecamatan Bandar Sribhawono Lampung Timur) [skripsi]. Bogor (ID). Institut Pertanian Bogor.

[Puskas BAZNAS] Pusat Kajian dan

Strategis Badan Amil Zakat Nasional. 2016. Outlook Zakat Indonesia 2016. Jakarta. Pusat Kajian Strategis BAZNAS.

Qardhawi, Y. (2011). Hukum Zakat Volume ke-1. Harun S, Hafidhuddin D, Hasanuddin, penerjemah. Jakarta (ID). Litera Antar Nus.

Ridlo, M. T. (2007). Zakat Profesi dan Perusahaan. Jakarta (ID). Institut Manajemen Zakat.

Sakaran, U. (2006). Metode Penelitian Bisnis. Jakarta (ID). Salemba Empat

Salmanpour, H., \& Issazadegan, A. (2012). Religiosity orientations and personality traits with death obsession. International Journal of 
Psychological Studies, 4(1),150157.

Sarwono, J. (2009). Statistika itu Mudah: Panduan Lengkap Untuk Belajar Komputasi Statistika Menggunakan SPSS 16. Yogyakarta (ID). Penerbit ANDI.

Sugiyono (2008). Metode Penelitian Pendidikan: (pendekatan kuantitatif, kualtitatif, dan $R \& D$. Bandung (ID). Alfabeta.

[UU RI] Undang-Undang Republik Indonesia. 2011. UU No 23 Tahun 2011 Tentang Pengelolaan Zakat. Jakarta (ID). UU Republik Indonesia.

Ventis, W. L. (1995). The relationship between religion and mental health. Journal of Social Issues, 51(2), 3348.
Amalia Agustin Syn

Bogor Agricultural University Indonesia

amaliasyn17@gmail.com

Khalifah Muhammad Ali

Bogor Agricultural University

Indonesia

khalifahma@gmail.com

Didin Hafidhuddin

Bogor Agricultural University

Indonesia

hafidhuddin@yahoo.com 